www.jmscr.igmpublication.org

Impact Factor 5.84

Index Copernicus Value: 83.27

ISSN (e)-2347-176x ISSN (p) 2455-0450

crossref DOI: _https://dx.doi.org/10.18535/jmscr/v5i4.140

Journal Of Medical Science And Clinical Research

IGM Publication

An official Publication of IGM Publication

\title{
A Comparasion of Perioperative Ramosetron and Ramosetron with Dexamethasone Prophylaxis for the Prevention of Postoperative Nausea and Vomiting Following Laparoscopic Cholecystectomy under General Anaesthesia
}

Authors

\section{Rakesh Nongthombam ${ }^{1}$, Ashem Jack Meitei ${ }^{2}$, Sinam Neetu Devi ${ }^{3}$ \\ Prof. Prithwis Bhattacharyya ${ }^{4}$, Maharabam Binarani ${ }^{5}$}

${ }^{1}$ Assistant Professor, Dept. of Anaesthesiology and Critical Care, JNIMS, Porompat, Manipur

${ }^{2}$ Assistant Professor, Dept. of Anaesthesiology and Critical Care, RIMS, Imphal, Manipur

${ }^{3}$ Postgraduate student, Dept. of Anaesthesiology and Critical Care, RIMS, Imphal, Manipur

${ }^{4}$ Head of Dept, Dept of Anaesthesiology and Critical Care, NEIGRIHMS Shillong, Meghalaya

${ }^{5}$ Senior Resident, Dept of Anaesthesiology and Critical Care, RIMS, Imphal, Manipur

Corresponding Author

Rakesh Nongthombam

Assistant Professor, Dept. of Anaesthesiology and Critical Care, JNIMS, Porompat, Manipur

\begin{abstract}
Introduction: Post Operative Nausea and Vomiting (PONV) is a well known complication following laparoscopic cholecystectomy under general anaesthesia ranges from 53-72\%. A reduction in the incidence of PONV following laparoscopic cholecystectomy will be highly beneficial for the patients to avoid patient dissatisfaction and peri-operative morbidity. This study have been undertaken to find out the efficacy of combination therapy of ramosetron with dexamethasone for the prevention of PONV following laparoscopic cholecystectomy under general anaesthesia.

Methods: 30 patients in each study group, age 18-65 years of either sex with ASA class I and II, scheduled for elective laparoscopic cholecystectomy under standardized general anaesthesia were enrolled in this randomized, double blind prospective study. Medication was given intravenously immediately before administration of induction agent. Enrolled patients were divided into two groups as RD group (ramosetron $0.3 \mathrm{mg}$ with dexamethasone $6 \mathrm{mg}$ and $R$ group (ramosetron $0.3 \mathrm{mg}$ ). The incidence of nausea, and vomiting, severity of nausea and need of rescue antiemetic were studied for the first 24 hours postoperatively at 0-6 hours and 6-24 hours and 0-24 hours.

Results: The incidence of nausea, PONV, rescue antiemetic were reduced in the RD group during 0-6 hours post operative periods while the incidence of vomiting was significantly reduced in RD group during 0-6 hours post operative $(P=0.003)$. The severity of nausea which measured by VRS was also significantly lesser in the RD group $(P=0.00)$. There were no clinically significant adverse effects during the study which required intervention. Following the study, patients were reported to have experienced satisfactory postoperative period.

Conclusions: Perioperative prophylaxis of ramosetron with dexamethasone combination given before the induction of anaesthesia is more effective regimen than ramosetron alone in preventing the incidence of PONV after elective laparoscopic cholecystectomy under general anaesthesia.

Keywords: Ramosetron, Dexamethasone, Postoperative nausea and vomiting, Verbal Rating Scale, Laparoscopic Cholecystectomy, General Anaesthesia.

\section{Introduction}

Laparoscopic surgery decreases the morbidity associated with cholecystectomy and has become

the most common treatment modality for symptomatic cholelithiasis. ${ }^{1,2}$ Post Operative Nausea and Vomiting (PONV) is a well known
\end{abstract}


complication following laparoscopic cholecystectomy under general anaesthesia ranging from 53$72 \% .^{3,4,5,6,7}$ A reduction in the incidence of PONV following laparoscopic cholecystectomy will be highly beneficial for the patients to avoid patient dissatisfaction and peri-operative morbidity.

Modalities like acupressure, transcutaneous electrical nerve stimulation (TENS), herbs, scopolamine, diphenhydramine, droperidol, promethazine, and metoclopramide have been used with limited efficacy. Often their uses have been associated with adverse effects ranging from dizziness, dry mouth, to severe cardiac arrhythmias and death. ${ }^{8}$

Serotonin (5-HT3 receptor antagonist) class of drugs are the new agents which are most commonly used as anti-emetics because of their rapid onset without sedative side effects. Among the various 5-HT3 receptor antagonists, ondansetron, the first of this category, was approved by Food and Drug administration in 1991 to be used in the treatment of PONV. ${ }^{9}$ Granisetron, the most recently approved of the group for the indication of PONV, lags significantly behind in the number of published trials to prove its efficacy. ${ }^{10}$ Ramosetron is a recently developed serotonin (5HT3 receptor) antagonist with potent antiemetic action and longer elimination half life ( 9 hours) than ondansetron (3.5 hours) and granisetron (4.9 hours). ${ }^{11,12}$ This highlights the scope for ramosetron to be effective for a longer duration, whereas, the commonly prescribed ondansetron's action lasts about 6 hours. Combination therapy has been shown to be superior to single agent as the cause of PONV is multifactorial and involves multiple pathways and receptors. Moreover, if an agent is ineffective against PONV, repeating a second dose of the same agent is unlikely to increase efficacy. ${ }^{13}$

There are many studies which have used the concept of multi-modal therapy for prevention of PONV showing excellent results in various categories of surgeries involving gastrointestinal, oto-rhinolaryngeal and gynaecological specialties. ${ }^{13}$ However, there are few studies involving ramosetron as part of the combination medication. Ramosetron alone has been found to be superior to granisetron and ondansetron for the management of PONV following laparoscopic cholecystectomy. ${ }^{14,15}$

In the study, we would like to test the hypothesis that combination of a long acting 5-HT3 receptor antagonist with dexamethasone which has a different mechanism of action will yield superior results compared to ramosetron administered alone for the prevention of PONV following laparoscopic cholecystectomy under standardized general anaesthesia.

\section{Materials and Methods}

This randomized, double blind prospective study was conducted at a teaching hospital in Meghalaya. After obtaining approval for the study from Institutional Ethical Review Board, a written informed consent was taken from each patient. In the present study, 30 patients in each study group, age 18-65 years of either sex with ASA class I and II, scheduled for elective laparoscopic cholecystectomy under standardized general anaesthesia were enrolled.

Pregnant patients, vomiting or retching within 24 hours before the operation, administration of antiemetics or steroids or psycho-active medications within 24 hours of operation, having cardiovascular, renal, hepatic, endocrine, gastrointestinal or neurological diseases were excluded in the study. In the study, patients were asked to provide their detailed medical history and their characteristic informations: - age, weight, history of previous PONV, motion sickness and smoking. Enrolled patients were randomly divided into $\mathrm{R}$ group $(\mathrm{n}=30)$ and $\mathrm{RD}$ group $(\mathrm{n}=30)$ and receive one of the two medications according to a computer generated randomized number table. The study drug was given intravenously, immediately before administration of induction agent. Patients in $\mathrm{R}$ group received ramosetron 0.3 $\mathrm{mg}$ and $\mathrm{RD}$ group ramosetron $0.3 \mathrm{mg}$ with dexamethasone $6 \mathrm{mg}$.

According to randomization, the study drug was drawn by the principal investigator in a $5 \mathrm{ml}$ 
syringe and was diluted upto $5 \mathrm{ml}$ with the sterile normal saline. For RD group, both the medications were drawn in a same syringe and diluted upto $5 \mathrm{ml}$ with the sterile normal saline to avoid visual bias. They were labelled with secret codes. The codes with secret keys were kept by the principal investigator to avoid evaluation bias by the follow-up investigator. The administrations of the medications as well as follow up evaluation were done by the investigator. All patients along with the investigator collecting the post operative data as well as the nurses involved in the post operative care of patients were blinded to the treatment received.

Night before the surgery, patients were given tab alprazolam $(0.5 \mathrm{mg})$, cap ranitidine $(50 \mathrm{mg})$ and nil per oral (NPO) after dinner. At morning, on the day of surgery, patients were given cap ranitidine (150 mg) with a sip of water. A standardized anaesthesia regimen was given during the study. Patients were premedicated with inj midazolam intravenously $(0.03 \mathrm{mg} / \mathrm{kg})$ and induced with inj thiopentone sodium $(5 \mathrm{mg} / \mathrm{kg})$, inj fentanyl (2 $\mu \mathrm{g} / \mathrm{kg})$ and inj vecuronium bromide $(0.1 \mathrm{mg} / \mathrm{kg})$ to facilitate endotracheal intubation. Anaesthesia was maintained with oxygen, intermittent inj vecuronium bromide $(0.02 \mathrm{mg} / \mathrm{kg})$ and isoflurane. At the end of the operation, muscle relaxant was reversed with inj neostigmine $(0.05 \mathrm{mg} / \mathrm{kg})$ and inj glycopyrolate $(0.01 \mathrm{mg} / \mathrm{kg})$. The incidence of post operative nausea and vomiting, severity of nausea, and the need for rescue antiemetic were studied for the first 24 hours after operation at 0-6 hours and 6-24 hours and 0-24 hours.

Patients were monitored for every 15 minutes in the post anaesthetic care unit (PACU) and every 2 hours in the ward except when asleep.

An episode of nausea was defined as a sensation of uneasiness and discomfort in the stomach with an urge to vomit. The intensity of nausea was assessed by using Verbal Rating Scale (VRS). ${ }^{8}$ Patients were asked to rate their degree of nausea during the assessment as none, mild, moderate, severe. Vomiting was either defined as a clinical symptom, the forceful expulsion of gastric contents through the mouth or nose, or retching (similar to vomiting with the exception that no gastric contents enter the pharynx, dry heaves).

Rescue medication for post operative nausea and vomiting (inj metoclopramide $10 \mathrm{mg}$ as initial rescue drug and inj promethazine $12.5 \mathrm{mg}$ as a second rescue drug) was given on patient's request or complaint of nausea (VRS-moderate) or vomiting. In order to minimize suffering from post operative nausea and vomiting, patients were educated to inform and request treatment when nausea and vomiting occur, during the post operative period.

In the study, we also evaluated adverse events and records during the entire overall observation periods. Lastly, patients were asked to rate their overall satisfaction with the anaesthetic experience on 5 points scale as: 1. Very good, 2. Good, 3. Fair, 4. Poor, 5. Very poor, at the completion of observation.

Sample size was calculated using the incidence of PONV following laparoscopic abdominal surgeries. For power calculation, we have taken the average incidence as $50 \%$. We aim to reduce the incidence to at least $15 \%$ so as to make the monotherapy an effective one. This was because, despite various modalities of intervention, PONV ranges between $10-30 \%$ following various surgical procedures under general anaesthesia. We hypothesize that combination therapy may bring the incidence further down making it a superior modality of treatment. With a 35\% improvement in the risk (one-tailed), 26 patients patient would be required but we enrolled 30 patients in each group to be investigated to find out statistically comparable results between the two groups at alpha power of $0.05 \%$ and beta power of $80 \%$. Data collected from the study were analysed using SPSS version 11.0 for windows (SPSS, Chicago, II, USA). Categorical data and proportional comparison were analyzed with Chi-square test with appropriate correction, if required. Significance of difference between mean values would be done with Student's t test. A P value of $<0.05$ was taken as level of significance. 


\section{JMSCR Vol||05||Issue||04||Page 20597-20606||April}

Table 1. Demographic profiles and preoperative co-morbidities of patients

\begin{tabular}{|c|c|c|c|c|c|}
\hline & $\begin{array}{c}\text { R group } \\
(n=30)\end{array}$ & $\begin{array}{c}\text { RD group } \\
(\mathbf{n}=30)\end{array}$ & Statistical test and value & $P$ value & inference \\
\hline $\begin{array}{l}\text { Age (years) } \\
\text { Mean } \pm \text { SD }\end{array}$ & $39.93 \pm 12.23$ & $36.63 \pm 11.87$ & $0.41 \#$ & 0.67 & NS \\
\hline $\begin{array}{l}\text { Weight (kg) } \\
\text { Mean } \pm \text { SD }\end{array}$ & $55.23 \pm 10.27$ & $55.63 \pm 9.25$ & $0.15 \#$ & 0.87 & NS \\
\hline Sex (M:F) & $1: 29$ & $3: 27$ & 1.07 \#\# & 0.30 & NS \\
\hline $\begin{array}{l}\text { BMI } \\
\text { Mean } \pm \text { SD }\end{array}$ & $23.67 \pm 4.11$ & $24.47 \pm 4.42$ & $0.72 \#$ & 0.72 & NS \\
\hline H/O motion sickness (\%) & $2(0.6 \%)$ & 0 & 2.07 \#\# & 0.15 & NS \\
\hline H/O Smoking (\%) & $5(1.5 \%)$ & $5(1.5 \%)$ & $0.00 \# \#$ & 1.00 & NS \\
\hline H/O PONV (\%) & 0 & 0 & - & - & - \\
\hline
\end{tabular}

(NS = not significant, \# = Ind t-test, \#\# = Chi square)

Demographic profiles were comparable between two study groups and found statistically not significant.

(Table 1)

Table 2. Intraoperative parameters during the study.

\begin{tabular}{|c|c|c|c|c|c|}
\hline & $\begin{array}{c}\text { R group } \\
\text { Mean } \pm \text { SD } \\
(n=30)\end{array}$ & $\begin{array}{c}\text { RD group } \\
\text { Mean } \pm \text { SD } \\
(n=30)\end{array}$ & $\begin{array}{l}\text { Statistical test* } \\
\text { and value }\end{array}$ & P-value & Inference \\
\hline Thiopentone (mg) & $245.83 \pm 6.61$ & $240.50 \pm 59.60$ & 0.34 & 0.73 & NS \\
\hline Duration of anaesthesia (mins) & $82.16 \pm 25.07$ & $75.33 \pm 22.51$ & 1.11 & 0.27 & NS \\
\hline Intraoperative fentanyl $(\mu \mathrm{g})$ & $85.33 \pm 25.96$ & $87.66 \pm 23.58$ & 0.36 & 0.71 & NS \\
\hline Duration of surgery (mins) & $73.66 \pm 23.85$ & $75.36 \pm 27.17$ & 0.25 & 0.80 & NS \\
\hline $\begin{array}{l}\text { Duration of pneumo- } \\
\text { peritoneum(mins) }\end{array}$ & $65.33 \pm 21.89$ & $61.16 \pm 20.41$ & 0.76 & 0.44 & NS \\
\hline Intra-abdominal pressure $(\mathrm{cm}$ of & $12.63 \pm 0.49$ & $12.53 \pm 0.50$ & 0.77 & 0.44 & NS \\
\hline
\end{tabular}

(NS = Not significant, $*=$ Ind t-test)

The total thiopentone, fentanyl dose consumed during induction, duration of anaesthesia, duration of surgery, duration of pneumo peritoneum and intra operative abdominal pressure fixed during pneumo peritoneum were comparable in both groups during the study. (Table 2)

Table: 3 Incidence of Nausea, Vomiting, PONV, VRS (Severity of nausea).

\begin{tabular}{|c|c|c|c|c|c|}
\hline & $\begin{array}{c}\mathbf{R} \text { group } \\
(\mathbf{n}=\mathbf{3 0})\end{array}$ & $\begin{array}{c}\text { RD group } \\
(\mathbf{n}=30)\end{array}$ & $\begin{array}{l}\text { Statistical test } * \text { and } \\
\text { value }\end{array}$ & $\begin{array}{c}\mathbf{P} \\
\text { value }\end{array}$ & Inference \\
\hline \multicolumn{6}{|l|}{ 0-6 Hours } \\
\hline Nausea & $17(56 \%)$ & $12(40.60 \%)$ & 1.66 & 0.20 & NS \\
\hline Vomiting & $10(33.33 \%)$ & $1(3.33 \%)$ & 9.02 & 0.003 & $\mathbf{S}$ \\
\hline PONV & $18(59.40 \%)$ & $12(40.60 \%)$ & 2.4 & 0.12 & NS \\
\hline Rescue - antiemetic & $11(37.30 \%)$ & $5(17.50 \%)$ & 3.06 & 0.08 & NS \\
\hline $\begin{array}{l}\text { VRS } \\
\quad \text { None } \\
\text { Mild } \\
\text { Moderate } \\
\text { Severe }\end{array}$ & $\begin{array}{c}4(13.33 \%) \\
14(46.67 \%) \\
9(30 \%) \\
3(10 \%)\end{array}$ & $\begin{array}{c}9(30 \%) \\
17(56.67 \%) \\
4(13.33 \%) \\
0\end{array}$ & 5.97 & 0.00 & $\mathbf{S}$ \\
\hline \multicolumn{6}{|l|}{ 6-12 Hours } \\
\hline Nausea & $10(33 \%)$ & $8(27.40 \%)$ & 0.32 & 0.57 & NS \\
\hline Vomiting & $3(10 \%)$ & 0 & 3.16 & 0.07 & NS \\
\hline PONV & $10(33 \%)$ & $8(27.40 \%)$ & 0.32 & 0.57 & NS \\
\hline Rescue -antiemetic & $7(24.10 \%)$ & $3(10.90 \%)$ & 1.92 & 0.16 & NS \\
\hline \multicolumn{6}{|l|}{ VRS } \\
\hline None & $5(16.67 \%)$ & $9(30 \%)$ & & & \\
\hline Mild & $18(60 \%)$ & $20(66.67 \%)$ & 5.82 & 0.12 & NS \\
\hline Moderate & $6(20 \%)$ & $1(3.33 \%)$ & & & \\
\hline Severe & $1(3.33 \%)$ & 0 & & & \\
\hline \multicolumn{6}{|l|}{ 0-24 Hours } \\
\hline Nausea & $19(62.70 \%)$ & $16(52.80 \%)$ & 0.62 & 0.43 & NS \\
\hline Vomiting & $10(33.33 \%)$ & $1(3.33 \%)$ & 9.02 & 0.003 & S \\
\hline PONV & $19(62.70 \%)$ & $16(52.80 \%)$ & 0.62 & 0.43 & NS \\
\hline Rescue antiemetic & $12(40.60 \%)$ & $7(24.10 \% 0$ & 1.93 & 0.17 & NS \\
\hline \multicolumn{6}{|l|}{ VRS } \\
\hline None & $13(43.33 \%)$ & $16(53.33 \%)$ & & & \\
\hline Mild & $13(43.33 \%)$ & $14(46.67 \%)$ & 4.34 & 0.11 & NS \\
\hline Moderate & $4(13.33 \%)$ & 0 & & & \\
\hline Severe & 0 & 0 & & & \\
\hline
\end{tabular}


The incidence of vomiting was significantly reduced in the $\mathrm{RD}$ group $(\mathrm{P}=0.003)$ during the $0-6$ hours post operative period. There were decrease incidence of nausea and PONV during the entire study periods though not statistically significant. Patients in the RD group sought lesser rescue anti emetic during the study period than in the $\mathrm{R}$ group. The severity of nausea which is measured by VRS was significantly decreased in the RD group, particularly during $0-6$ hours post operative period. (Table 3)

Table: 4 Incidence of adverse effects and patient satisfaction score

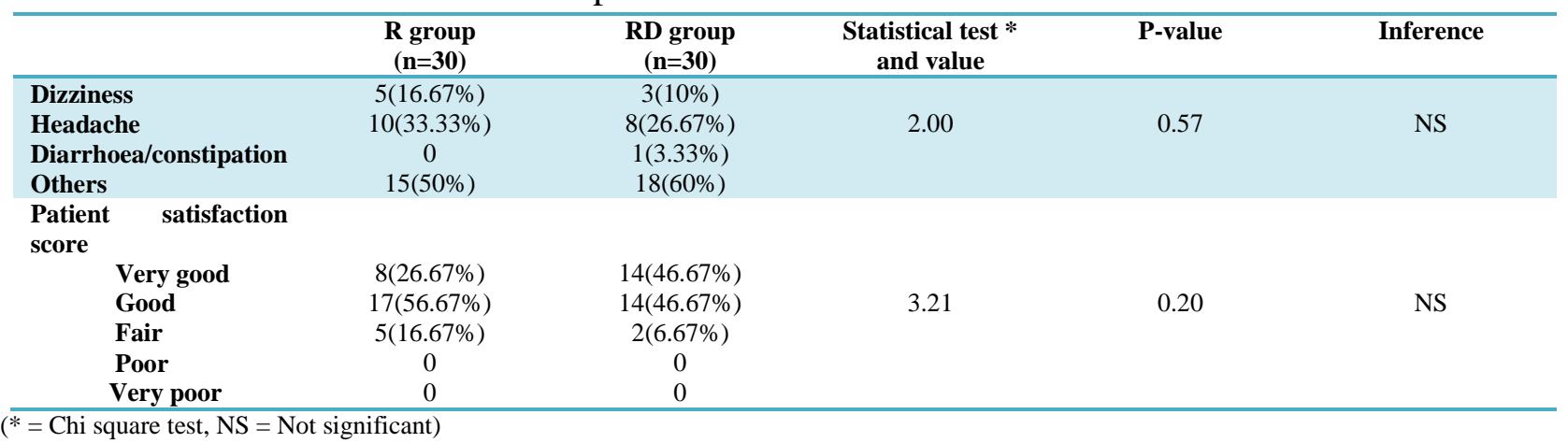

During the entire study periods, there were no serious adverse effects in the patients which required clinical intervention. Study was conducted and completed smoothly. All the participating patients in the both the group were satisfactory with anaesthetic techniques. (Table 4)

\section{Discussion}

Post operative nausea and vomiting is a common, undesirable complication after laparoscopic cholecystectomy under general anaesthesia. The exact aetiology of PONV is complex which is considered to involve multifactorial pathway with the vomiting centre receiving afferents from cerebral cortex, viscera and chemo receptor trigger zone (CTZ). There are certain independent perioperative risk factors considered to contribute to the causes of PONV. ${ }^{16}$ History of migraine, history of PONV or motion sickness in a child's parent or sibling, better ASA physical status, intense preoperative anxiety, certain ethnicities or surgery types, decreased perioperative fluids, crystalloid versus colloid administration, increasing duration of anaesthesia, general versus regional anaesthesia or sedation, balanced versus total intravenous anaesthesia, and use of longeracting versus shorter-acting opioids are some of the possible risk factors to PONV. It may be mentioned that the knowledge of risk factors and causative pathway of PONV are necessary for the satisfactory management of PONV.

Pharmacological therapy consists of anticholinergics (e.g. scopolamine), butyrophenone (e.g. droperidol), benzamide (e.g metoclopramide) and antiserotonin (e.g. ondansetron) were able to control PONV to certain limited extend. Non traditional antiemetics, e.g. propofol, dexamethasone and midazolam, have also been used in the prophylaxis of PONV. However, antiemetics in the group of anticholinergic, antihistaminic, butyrophenone and benzamide group of drugs are associated with significant undesirable side effects e.g. sedation, hypotension, dry mouth, restlessness and extrapyramidal symptoms. Antiserotonins (5-HT3 receptor antagonists) are one of the most effective treatment remedy available for the prevention of PONV. Various studies were conducted comparing antiserotonins (ondansetron, granisetron, ramosetron) and other drugs like dexamethasone, droperidol, metoclopramide and saline showing highly variable results in various emetogenic surgeries. ${ }^{12,15,17,18,19}$

Ramosetron hydrochloride was first developed in Japan and its antiemetic utility was demonstrated in the chemotherapy induced nausea and 
vomiting. ${ }^{20}$ It is also reported that ramosetron is more effective among the available 5-HT3 receptor antogonist agents for preventing PONV in the highly emetogenic surgeries ${ }^{21,22,23,24,25}$ and chemotherapy induced PONV when ramosetron was given prior to administration of anti cancer drugs such as 5-fluro uracil. ${ }^{26}$

Dexamethasone, a long acting glucocorticoid and a potent synthetic analogs of cortisol which has powerful anti-inflammatory and immunosuppressive effects, was reported to use as an effective emetic agent in the chemotherapy induced nausea and vomiting, ${ }^{27}$ elective tonsillectomy ${ }^{28,29}$ and major gynaecological surgeries. ${ }^{30}$ It is also further reported that dexamethasone has decreased the post operative pain and fatigue therefore enabling the faster resumption of recreational activities in the postoperative periods. $^{31}$

Multi-modal emetic prophylaxis has shown a better management strategy in the prevention of PONV in high risk population thereby increasing the patient satisfaction. ${ }^{32}$ Combination of 5-HT3 receptor antagonists and dexamethasone has shown effectiveness in preventing PONV in chemotherapy induced nausea and vomiting, ${ }^{33}$ major gynaecological surgeries ${ }^{34,35}$ and laparoscopic cholecystectomy. ${ }^{36,37,38}$

Ramosetron with dexamethasone combination prophylaxis was reported to provide an effective modality for the prevention of chemotherapy induced acute and delayed emesis with no side effects, ${ }^{39,40}$ laparoscopic cholecystectomy ${ }^{41}$ and thyroidectomy. ${ }^{42}$

During the study, preoperative history of motion sickness, previous PONV, total anaesthetic drugs consumed, duration of anaesthesia, duration of surgery, duration of carbon dioxide insufflations (pneumo-peritoneum) and intra-abdominal pressure maintained during pneumo-peritoneum were comparable in both study groups. Patients in both groups also consumed approximately similar amounts of intravenous fentanyl for providing adequate analgesia. None of the enrolled patients left during the study period.
In the present study, the total incidences of nausea, vomiting and PONV were found decreased in the RD group than R group where the incidence of vomiting was decreased among the RD group significantly $(P=0.003)$ during the first 0-6 hours postoperative peroid. This finding is found better than the studies reported by Rajeeva $\mathrm{V}$ et al. ${ }^{35}$ and Fujii $\mathrm{Y}$ et al. ${ }^{43}$ in term of duration of PONV free periods, rescue antiemetic requirements and side effects profiles of the anti emetics used. These might be attributed to the prolonged half life ( $9 \mathrm{hrs}$ ), high affinity for 5-HT3 receptor and minimum sides effect of ramosetron $^{8,44,24,45}$ and the contribution by dexamethasone (mechanism may be decreased production/secretion of serotonin and antiprostaglandin action) ${ }^{14,30}$ to the anti emetic effect of ramosetron as a part of multi modal therapy. ${ }^{13,46,32}$ During the study, few patients from both groups complained of non specific symptoms which were tolerable. Among the undesirables side effects, headache was the most common followed by dizziness which was in conformity with other anti serotonins.

There were two other studies ${ }^{41,42}$ which have already published using similiar combination regime for the prevention of PONV following surgical procedures. However there were certain differences from these published studies during the conduct of the study in term of the timing and doses of study drugs administration and anaesthetic agents used which might influence the results. The incidence of nausea, vomiting, PONV, nausea severity (measured by VRS in the present study and $\mathrm{NRS}^{41}$ ) and rescue antiemetic in all the three study were decreased. However, the decreased incidence of vomiting and nausea severity scale (VRS) could be reported (statistically) significantly only during the first 0-6 hours post operatively in the present study, whereas the decreased incidence of PONV, nausea severity, rescue antiemetic during 0-24 hour postoperatively $^{42}$ and the decreased incidence of rescue anti emetic during 0-24 hours postoperatively with decreased nausea severity 
scale (NRS) during the entire 0-48 hours study periods. $^{41}$

During the study, though there is some debate regarding the actual dose of ramosetron ${ }^{23}$ and dexamethasone $^{47}$ for the prophylaxis of PONV, we used $0.3 \mathrm{mg}$ of ramosetron $(6 \mu \mathrm{g} / \mathrm{kg})$ and $6 \mathrm{mg}$ dexamethasone though in the other published study $8 \mathrm{mg}$ dexamethasone was used.

There are side effects of study drugs viz:dizziness, headache which are common in all group. Clnically serious adverse events did not occur during the study period. Recently, several investigators have reported the effectiveness of ramosetron on the treatment of irritable bowel syndromes with diarrhoea. ${ }^{48}$

Satisfaction with antiemetic prophylaxis was better in ramosetron with dexamethasone combination prophylaxis (though not statistically not significant, $\mathrm{P}=0.20$ ).

There were certain limitations during the study which includes: - devoid of control group, subjectivity on part of patients while reporting nausea, vomiting and smaller in sample size. The study does not includes control group for the fear that patients devoids of appropriate antiemetic following highly emetogenic surgeries may exposed to risk of PONV which is unpleasant therefore considered unethical.

The absence of complete prevention of PONV in the study could be attributed to the multifactorial pathways of PONV and various independents risk factors like preoperative history of PONV, motion sickness, female gender ${ }^{7,49}$ ( more so during menstrual periods) and use of inhalational anaesthesia (isolflurane), opioids (inj fentanyl), hydration status and even with inj neostigmine and inj glycopyrolate. ${ }^{18,49}$ Further studies with minimum preoperative risks and larger sample size will still necessary in order to demonstrate complete absence of PONV following such highly emetogenic surgeries.

\section{Conclusion}

Perioperative prophylaxis of ramosetron with dexamethasone is more effective than ramosetron alone in preventing the incidence of PONV after laparoscopic cholecystectomy under general anaesthesia.

\section{Reference}

1. NIH Consensus Development Panel on Gallstones and Laparoscopic cholecystectomy. Gallstones and laparoscopic cholecystectomy. JAMA 1993; 269: 1018-24.

2. Begos DG, Modlin IM. Laparoscopic cholecystectomy: from gimmick to gold standard. J Clin Gastroenterol 1994; 19: 325-35.

3. Fredman B, Jedeikin R, Olsfenger D, Flor P, Gruzman A. Residual pneumoperitoneum, a cause of post operative pain after laparoscopic cholecystectomy. Anaesth Anal 1994; 79: 152-4.

4. Thune A, Appelgren L, Haglind E. Prevention of post operative nausea and vomiting after laparoscopic cholecystectomy. Eur J.Surj. 1995; 161: 265-8.

5. Naguib M, Bakry AK, khoshim MH, Channa AB, Gammal K, Elhattab YS, Attia M, Jaroudi R, Saddique A. Prophylactic antiemetic therapy with ondansetron, tropisetron, granisetron and metoclopramide in patient undergoing laparoscopic cholecystectomy: a randomized double-blind comparison with placebo. Can J.Anaesth1996; 43: 226-31.

6. Koivurauta MK, Laora E and Ryhanen PT. Anti emetic efficacy of prophylactic Ondansetron in laparoscopic cholecystectomy: A randomized, double-blind, placebo controlled trial. Anaesthesia 1996; 51: 52-5.

7. Mraovic B, Jurioic T, Kogler Majeric V, Sustic A. Intra peritoneal bupivacaine for Analgesia after Laparoscopic cholecystectomy. Acta. Anaesthesia, Scand 1997; 41: 193-6.

8. Christian C.Apfel. Post operative nausea and vomiting. Ronald D.Miller. (Eds); Miller Anaesthesia. $7^{\text {th }}$ edition. Philadelphia, Churchill Livingstone, 2010. pp. 2729-53. 
9. Adam k Jacob, Sandra L. Kopp, Douglas R. Bacon and Hugh M.Smith. The history of Anaesthesia. In: Paul G. Barash, Bruce F.Cullen, Robert K. Stoelting, Michael K. Cahalan M.Christine Stock (eds) Clinical Anaesthesia. $\quad 6^{\text {th }}$ ed. Philadelphia, WOLTERS KLUWER/LIPPINCOTT WILLIAM \& WILKINS, 2009. P-18.

10. Paul H. Ting. Post operative Nausea and vomiting. An overview www.anaesthesiologyinfo.com

11. Rabasseda X. Ramosetron, a 5-HT3 receptor antagonist for the control of nausea and vomiting. Drugs Today (Barc). 2002 Feb; 38(2): 75-89.

12. Gan TJ. Selective Serotonin 5-HT3 receptor antagonist for post operative nausea and vomiting, are they all the same? CNS Drugs 2005; 19: 225-38.

13. Jansen K, Kehlet $\mathrm{H}$ and Lund CM. Post operative recovery profile after laparoscopic cholecystectomy: a prospective observational study of a multi-modal anaesthetic regime.Acta anaesthesiology Scand.2007; 51(4): 464-71.

14. Fujii Y, Saitoh Y, Taneka H, Toyooka H. Comparison of ramosetron and granisetron for preventing PONV after laparoscopic cholecystectomy. Can, Anaesthesia, 1999; 46: 991-93.

15. Ryu J, So YM, Hway J, Do SH. Ramosetron vs. ondansetron for prevention of post operative after laparoscopic. Surg Endos 2010; 24(4): 812-7.

16. Gan TJ. Risk factors for postoperative nausea and vomiting. Anesth. Analg. 2006 Jun; 102(6): 1884-98.

17. Jones AL, Hill AS, Soukop M, Hutcheon AW, Cassidy J and Kaye SB. Comparison of dexamethasone and ondansetron in the prophylaxis of emesis induced by moderately emetogenic chemotherapy. Lancet 1991; 338: 483-7.

18. Watcha MF and white PF. Post operative nausea and vomiting, its aetiology, treatment and prevention. Anaesthesiology 1992; 77(1): 162-8.

19. McKenzie R, Tantisira B, Karambelkar DJ, Riley $\mathrm{TJ}$ and Abdelhedy $\mathrm{H}$. Comparison of ondansetron plus saline and ondansetron plus dexamethasone in the prevention of post operative nausea and vomiting. Anaesthesia Analgesia 1994; 75(5): 961-4.

20. Tsukagoshi S. A new antiemetic ramosetron hydrochloride. Gan To Kagaku Ryoho. 1997 Feb; 24(3): 371-80.

21. Fujii Y, Saitoh Y, Tanaka H, Toyooka H. Comparison of ramosetron and granisetron for preventing postoperative nausea and vomiting after gynaecologic surgery. Anesth Analg. 1999 Aug; 89(2): 476-9.

22. Fujii Y, Saitoh Y, Tanaka H, Toyooka H. Ramosetron vs. granisetron for the prevention of postoperative nausea and vomiting after laparoscopic cholecystectomy. Can. J Anaesth. 1999 Oct; 46(10): 991-3.

23. Fujii Y, Tanaka H. Double-blind, placebocontrolled, dose-ranging study of ramosetron for the prevention of nausea and vomiting after thyroidectomy. Clin Ther. 2002; 24(7): 1148-53.

24. Fujii Y. Current review of ramosetron in the prevention of postoperative nausea and vomiting. Curr Drug Saf. 2011 Apr; 6(2): 122-7.

25. Ryu JH, Jeon YT, Hwang JW, Oh AY, Moon JY, Ro YJ, Kim CS, Chen C, Apfel $\mathrm{CC}$, Do SH. Intravenous, oral, and the combination of intravenous and oral ramosetron for the prevention of nausea and vomiting after laparoscopic cholecystectomy: a randomized, doubleblind, controlled trial. Clin Ther. 2011 Sep; 33(9): 1162-72.

26. Kyubo Kim, Eui Kyu Chie, Jin Young Jang, Sun Whe Kim, Do Youn Oh, Seock Ah Im, Tao You Kim, Yung Jue Bang and Sung W.H. Ramosetron for the prevention of nausea and vomiting during 5-Fluro 
uracil based chemo radiotherapy for pancreatico- biliary cancer. Jpn j Clin Oncol 2009; 39(2): 111-5.

27. Aapro MS and Alberts DS. High dose dexamethasone for prevention of cisplatin induced vomiting. Cancer Chemother Pharmacol 1981; 7 (1): 11-4.

28. Splinter WM and Robert DJ. Dexamethasone decreased vomiting after elective tonsillectomy in 133 healthy children. Anaesthesia Analgesia. 1996; 83(5): 913-6.

29. Pappas ALS, Sukhani R, Hotaling AJ, Mikatstens M, Javorski JJ and Donzelli J. The effect of preoperative dexamethasone on immediate and delayed post operative morbidity in children undergoing adenotonsillectomy. Anaesthesia Analgesia.1998; 87(1): 57-61.

30. Liu K, Hsu CC and Chia YY. Effect of dexamethasone on post operative emesis and pain. British Journal of Anaesthesia.1998; 80: 85-6.

31. Thue B, Klarskov BRN, Henrik $k$ and Jacob R. Preoperative dexamethasone improves surgical outcome after laparoscopic cholecystectomy: a randomized, double-blind, placebo controlled trial. Annals of surgical.2003; 238(5); 651-60.

32. Scuderi PE, James RL, Harris L, Mims GR. Multimodal antiemetic management prevents early postoperative vomiting after outpatient laparoscopy. Anesth Analg. 2000 Dec; 91(6): 1408-14.

33. Fujii $Y$, Tanaka $H$ and Toyooka $H$. Granisetron and dexamethasone combination reduces postoperative nausea and vomiting. Can.J.Anaesth 1995; 42(5pt1): 387-90.

34. Lopez-Olaondo L, Carrascosa f, Pueyo FJ, Mondero P, Busto $\mathrm{N}$ and Saez A. Combination of ondansetron and dexamethasone in the prophylaxis of post operative nausea and vomiting. British
Journal of Anaesthesia.1996; 76(6): 835840.

35. Rajeeva V, Bhardwaj N, Batra YK and Dhaliwal LK. Comparison of ondansetron with ondansetron dexamethasone in prevention of PONV in diagnostic laparoscopy. Can J. Anaethe.1999; 46(1): 40-4.

36. Wang JJ, Ho ST, Ven YH, Lin MT, Chen KT, Huang JC and Tzeng JI. Small dose dexamethasone reduces nausea and vomiting after laparoscopic cholecystectomy, a comparison of tropisetron with saline. Anaesthesia Analgesia.2002; 95: 229-32.

37. Biswas BN and Rudra A. Comparison of granisetron and granisetron plus dexamethasone for the prevention of post operative nausea and vomiting after laparoscopic cholecystectomy. Acta anaesthesiology Scand. 2003; 47(1): 7983.

38. Fujii Y, Tanaka $\mathrm{H}$ and Kawasaki T. A randomized, double-blind comparison of granisetron alone and combined with dexamethasone for post laparoscopic cholecystectomy emetic symptom. Current therapeutic research. 2003; 64(8): 514-21.

39. Vovavud N, Sriuranpong. Phase II trial of ramosetron plus dexamethasone in the prevention of cisplatin induced nausea and vomiting. Med Assoc Thai 2005; 88(12): 1790-6.

40. Ching-Liang Ho, Wu-Chou Su, RueyKuen Hsieh, Zhong-Zhe Lin and Tsu-Yi Chao. A randomized, double-blind, parallel, comparative study to evaluate the efficacy and safety of ramosetron plus dexamethasone injection for the prevention of acute chemotherapy-induced nausea and vomiting. Jpn J Clin Oncol 2010; 40(4): 294-301.

41. Jung Hee Ryu, Ji Eun Chang, Hye Rim Kim, Jung Won Hwang, Ah Young Oh, Sang Hwan Do. Ramosetron vs ramosetron plus dexamethasone for the 
prevention of postoperative nausea and vomiting (PONV) after laparoscopic cholecystectomy: Prospective, randomized, and double-blind study. International Journal of surgery 11 (2013) 183-7.

42. Younghoon Jeon, Hyunjee Kim, Kyung Hwa Kwak. Comparison of ramosetron, dexamethasone and a combination of ramosetron and dexamethasone for the prevention of postoperative nausea and vomiting in Korean women undergoing thyroidectomy: A double-blind, randomized, controlled study. Curr Ther Res Clin Exp. 2010; 71: 78-88.

43. Fujii Y, Saitoh Y, Tanaka H and Tayooka H. Granisetron and dexamethasone combination for the prevention of nausea and vomiting after laparoscopic cholecystectomy. Eur. J. Anaesthesiol. 2000; 17: 64-8.

44. Ryu J, So YM, Hwang J, Do SH. Ramosetron versus ondansetron for the prevention of postoperative nausea and vomiting after laparoscopic cholecystectomy. Surg Endosc. 2010 Apr; 24(4): 812-7. Epub 2009 Aug 26.

45. Kim WO, Koo BN, Kim YK, Kil HK. Ramosetron for the prevention of postoperative nausea and vomiting (PONV): a meta-analysis. Korean J Anesthesiol. 2011 Nov; 61(5): 405-12. Epub 2011 Nov 23.

46. Liu YH, Hsu CC and Chia YY. The effective dose of dexamethasone for antiemesis after major gynaecological surgery. Anaesthesia Analgesia.1999; 89: 1316-8.

47. Henze I, Walder B and Tramer MR. Dexamethasone for the prevention of post operative nausea and vomiting: a quantitative systemic review. Anaesthesia Analgesia.2000; 90: 186-94.

48. Fukudo S, Kinoshita Y, Okumura T, Ida M, Akiho H, Nakashima Y, Nishida A,
Haruma K. Ramosetron reduces symptoms of irritable bowel syndrome with diarrhea and improves quality of life in women. Gastroenterology. 2016; 150(2): 358-66.

49. Cohen MM, Duncan PG, DeBoer DP, Tweed WA. The postoperative interview: assessing risk factors for nausea and vomiting. Anesth Analg. 1994; 78: 7-16. 